\title{
European research framework set to expand
}

\section{Alison Abbott, Munich}

Officials in Brussels are drawing up plans for the European Union's Seventh Framework Programme of Research (FP7), and the proposed scope may cheer the continent's scientists.

The officials hope to avoid major revisions to the existing, Sixth Framework Programme (FP6) - but FP7 will be twice as big and include a more extensive basicresearch component.

The proposal still has to survive months of political wrangling that will follow its publication by the European Commission in April. But early indications of its content suggest that the form-filling requirements that irked researchers in previous programmes will not worsen significantly.

According to commission insiders, the 'instruments' of the programme, such as the transnational Integrated Projects and Networks of Excellence, will remain the same. Instruments have sometimes changed radically between each Framework, so that experience gained in applying for one programme did not help much in the next.

The thematic areas are likely to remain the same: life sciences, information sciences, nanosciences, aeronautics, food quality, energy and governance. But they will be joined by two new ones: space science and security.

In preparing its plans, the EU Research Commission has taken into account various political demands, including the 'Lisbon

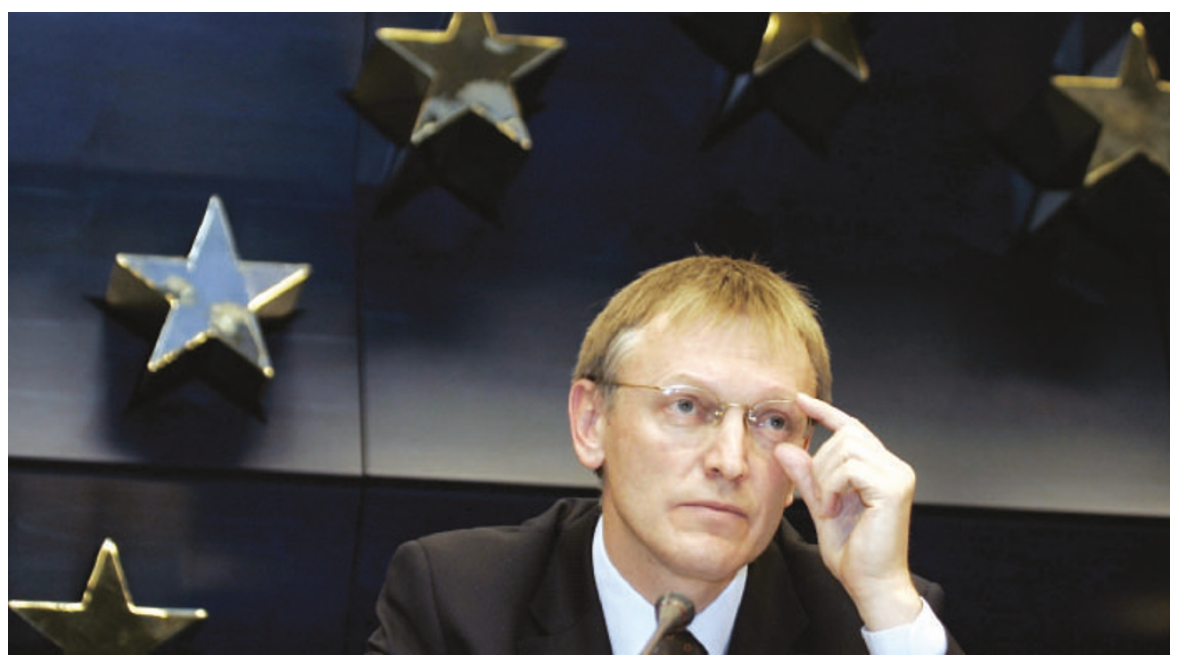

In the frame: Janez Potočnik, an EU commissioner, is bullish about Europe's research programme.

objectives', set out in 2000, which aim to increase Europe's long-term competitiveness by strengthening research. In view of these, it will request that the four-year budget be more than doubled to some $€ 30$ billion (US $\$ 40$ billion).

After publication, the plan has to be approved by both the European Parliament and the European Council. To ensure a smooth transition from FP6, which runs until 2006, final approval will be sought this September. This approval process has previously reduced Framework programmes and increased the bureaucratic burden on grantees. But Janez Potočnik, the Slovenian economist who became EU research commissioner in November, remains confident. "I hope we won't be forced to cut priorities that were favoured in Lisbon," he says, adding that he doesn't expect this to happen.

A separate budget for a European Research Council will probably be included in the proposal. Some fear that the creation of this council could make the basic-research component of FP7 politically vulnerable, but Potočnik says he will fight to maintain it. "Basic research is fundamental to our plans at all levels," he says.

\section{Health rules may hamper Japanese import of lab mice}

Ichiko Fuyuno, Tokyo

Japan is to introduce a new regulation for animal imports, in an effort to prevent outbreaks of diseases that could infect humans. But biologists worry that the rule will simply make it harder to do research.

From September 2005, the health ministry will require importers of birds and most mammals to provide a health certificate issued by the government of the exporting country. For rodents - including rats and mice - these certificates must show that the animals are clear of seven diseases that are infectious to humans, including plague, rabies and monkeypox. Imports of wild rodents will be banned outright.

The rule, which is part of a wider clampdown on infectious diseases in Japan, will also require certificates for frozen carcasses, but not for frozen embryos.

The ministry says the main purpose of the rule is to keep wild rodents out of Japan. But it has decided not to exempt laboratory mice and rats that are bred abroad in strictly

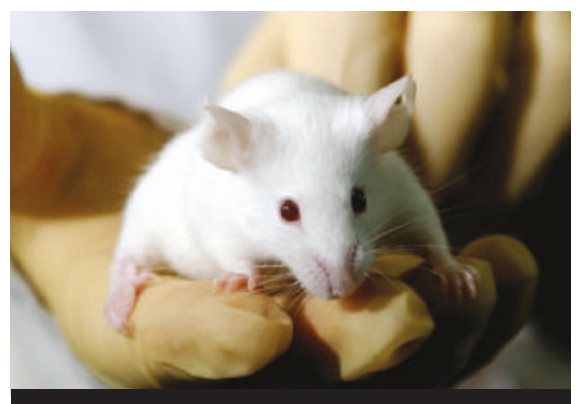

On form: lab animals will have to be certified as healthy before they can be imported into Japan.

controlled conditions, for fear that some importers might abuse such exemptions.

The move comes at a time when demand for rats and mice is growing sharply. At a 16 December meeting to explain the new requirement, 140 researchers complained that it would make the import of lab animals time-consuming and expensive. "This will affect our research,” said Toshihiko Shiroishi, who studies mouse development at the
National Institute of Genetics in Shizuoka. Many institutions and universities in the United States and Europe already issue hygiene certificates indicating that rats or mice are free from specific pathogens. "We wonder why existing certificates won't work - and how much government certificates can help to prevent disease," Shiroishi says.

He adds that the government's approach is unreasonable, considering that imports of lab rats or mice are not known to infect humans. Researchers say it will be difficult to get exporting countries to test animals for diseases such as rabies. Other countries have different rules on lab imports - the United States, for example, imposes few conditions, according to Japan's health ministry.

The ministry plans to ask exporting countries to be cooperative in issuing certificates. But Tadao Serikawa, director of the Institute of Laboratory Animals at Kyoto University, says it's not clear that this will help. The result could be "a big loss for scientific research" in Japan, he predicts. 